\title{
A Study on the Influences of Politeness Strategies on Headteacher's Work
}

\author{
Tang TANG \\ Beijing Wuzi University, Fuhe Street No.1, Tongzhou District, Beijing, China, 101149
}

Keywords: Politeness strategies, Influence, Headteacher's work.

\begin{abstract}
This paper analyzes the polite expressions and methods in the daily work of headteacher by using the theories of politeness strategy from pragmatics and provides suggestions on politeness strategies and improvement of working methods in headteacher's work. It is beneficial to activate classroom atmosphere, harmonize the teacher-student relationship, improve students' enthusiasm and help the formation of favorable class atmosphere and the healthy growth of students through the proper and smart application of politeness strategies. And through the analysis of the polite strategies application, it can be safely concluded that politeness strategies are an important step to help headteacher to accomplish the daily class management work, so headteacher need to attach great importance to the exploration of politeness strategies.
\end{abstract}

\section{Introduction}

From the perspective of psychics, "respect" is a need of human beings. Students, in particular, need more respects from others as their personalities are developing and forming, so they will become more capable, positive, confident and creative in life and study. Politeness strategies are the summary of headteacher's working methods. The application of the politeness strategies is a kind of skill; in addition, an art and a need to implement the quality-oriented education. It can activate classroom atmosphere, harmonize the teacher-student relationship, improve students' enthusiasm and help the formation of favorable class atmosphere and the healthy growth of students through the proper and smart application of politeness strategies. Only when loving students can teachers actually care for students; only when respecting students can teachers require students; only when understanding students can teachers educate students. Politeness strategies are an important step to help headteacher to accomplish the daily class management work, so headteacher needs to attach great importance to the exploration of politeness strategies.

Headteachers in elementary and secondary school are the organizers and education administrators of class and the backbones of teaching work and ideological and moral education. To some extent, headteacher is the guider for the healthy growth of primary and secondary school students. Therefore, it is very necessary to adopt some politeness strategies, as decided by the characteristics and nature of headteacher's work and advocated by the educational ideas of people orientation and respect. However, this is often ignored by some headteachers. As adolescents' psychology is sensitive and fragile, if they are not respected by their teachers, all kinds of conflicts will arise between teachers and students. However, if politeness strategies are properly applied, these conflicts can be relieved, avoided or eliminated, so headteacher's work will be more effective.

Politeness strategies are ways of communication used by people consciously or unconsciously for the sake of politeness in communication. "Language is an important way to express politeness." (He, 1997: 99), thus politeness strategies are often realized through language. Politeness strategies are divided into two perspectives-positive and negative. People also concern two perspectives of face in communication, which are positive face and negative face. Positive face means the desire to be accepted and praised by others; negative face means people have their own freedom and will not make themselves lose face due to yield to others, being intervened or interfered. The speaker should use positive politeness strategies and respect the hearer to save his face, to ensure the positive face of the hearer is not threatened. 


\section{Application of Positive Politeness Strategies}

In the class affair of headteacher, positive politeness strategies can be divided into the following types:

\section{Showing Agreement (Including Teachers’ Agreement on Students’ Views, Opinions or Interest, etc.)}

Students in adolescence starve for affirmation and respect from others. The headteacher should properly use this politeness strategy and praise those students who answer questions correctly, make progress in their studies or accomplish learning tasks excellently, abide by class rules and school disciplines, hold positive suggestions for the healthy development of the class, etc. For instance, after laboring practice, teacher should summarize: “All of you have accomplished the task well”. When answering questions, if students raise hands bravely and answer the question well, the teacher should encourage the student in time "You have made a good answer and I totally agree with you." When student give his/her ideas about class management, the headteacher should encourage: "It's a good thing to provide suggestions for the class work. I support you. It's a good idea! ......" These simple words and sentences can give students confidence and motivation. Teachers should not use mean and sharp expressions to blame students, so as to show tolerance, save students' face and protect their learning initiatives.

\section{Satisfying Students' Reasonable Demand to the Greatest Extent}

Excellent headteachers should "understand students' aspiration and be confident to satisfy their aspiration” (Jia, 1996: 43). During handling class affairs, headteacher should allow students to ask questions and express opinions, to satisfy their curiosity. For example, it will be beneficial to hold a mid-autumn evening party, carry out all kinds of activities to encourage students to love the class and put forward "Abiding by disciplines and studying hard are the best contribution made to the class", which will have great promotion effect on class management. If students' questions are rejected by teacher, students' learning interest will be reduced and they will give up on themselves, which will bring adverse impact on the whole class. Therefore, headteacher should solve the questions and difficulties for students patiently and detailedly.

\section{Showing Your Cooperative Attitude with Students}

Students will definitely encounter with some problems and difficulties in study and life,some of which may be caused by teacher's “unclear explanations or misunderstandings" (Liu, 2002: 96). At this time, headteacher should show his/her cooperative attitude. For example, once a student told me that our PE teacher had prejudice to our class and was very rigor to our class but very nice to other class. I said: "Maybe you are right, but I will not reply you until I check it out." At this time, you cannot just negate the student totally for preserving teacher's prestige and speak out something like "Remember, anyway, what teachers say are always right." If you do that, it is easy to cause head-on confrontation between student and teacher. If students get the right and satisfied reply in other ways, headteacher will be totally discredited and lose trust of students or even worse, students' learning weariness will be induced, which will cause negative influence on education and teaching management.

\section{Getting Close to Students}

The amiable relation between headteachers and students is an important factor for successful education. At ordinary times, headteacher should get to know and get close to students, be an intimate friend of students and pay attention to inputting affection (Jia, 1996: 102). For example, on a self-study night, I found that the class monitor was seemed to be upset, so I talked to her then. She said her parents cared more about her elder sister than herself. I enlightened her: "Your parents would not have this kind of idea. Maybe it is because your sister is going to take the senior high school 
entrance examination. Your parents care more about your sister and hope your sister can keep her mind on study and finally can enter into a better school. Besides, you are so thoughtful and intelligent. That's why your parents trust you. You need not to be upset.” Finally she smiled. On the contrary, imperative utterance will make the student think that the teacher is indifferent, unfriendly and impolite. Students are required to respect the teacher while teachers are not. In this way, a high wall is established between students and teacher, which is disadvantageous to the class management of the headteacher.

\section{Influencing Students with Positive Attitude}

The special professional role of teacher has immeasurable influence on students' learning attitude. "In study, it is very important to keep a positive attitude. However, students' attitudes, especially their learning mood in the class, are easily affected by teacher to a large extent." (Qiu, 1993: 58) For example, if some student has prejudice or misunderstanding against some teacher or some teacher has prejudice or misunderstanding against some student, or the teacher is not in the mood, student will lose confidence in the subject this teacher teaches. Thus, headteacher should know how to control his/her emotion and regulate the relationship between teachers and students or influence students through language so students can face the study and the life with normal attitude.

\section{Effect of Negative Politeness Strategy}

Negative politeness strategies mainly include the following aspects in class affair of headteacher:

\section{Giving Students Freedom to Choose}

When someone makes request, order or suggestion to the other, it actually invades the person's private space (He, 1997: 89). The person who makes request, order or suggestion has to take some actions to prevent face of the other from being hurt. For instance, when the headteacher requests a student to accomplish a task or answer some questions, if the student rejects or is unwilling or can not to do so, the headteacher should keep his/her composure, consider student's mental feeling and must not compel the student to do so for fear that student's psychological inversion is induced. In this way, both face of the student and the teacher can be kept.

\section{Apologizing to Students}

It is inevitable that headteachers will make some mistakes in their work and sometimes some mistakes are not the event or utterance itself. For example, a headteacher found that a piece of window glass was broken by some student and severely criticized that student. Later on, the headteacher found that the window glass was broken when the student was doing classroom cleaning. As the event occurs in such a special environment in the classroom, student's pride and confidence will be hurt. At this moment, the headteacher should pocket his/her pride and apologize to the student. Maybe the headteacher will lose his/her face by doing so, but if the speaker apologizes to the hearer for hurting his face, the hearer's harm will be reduced.

\section{Expressing Thanks to Students}

Some teachers believe: if the speaker expresses thanks to the hearer, the speaker will lose his/her face. However, expressing thanks in class or in life is also a kind of politeness strategy. Teacher will not lose his/her face by doing so; on the contrary, the teacher-student relationship will become more intimate and harmonious. Student will believe he/she is respected and his/her endeavor is confirmed by the teacher. By expressing thanks to students, the teacher expresses more and the content expressed becomes more important. For instance, once I found that there were no chalks, and then I 
asked a student to go to the office to grasp some. After that, I expressed thanks to the whole class. All students think that I am equal to them and can easily get close.

\section{Keeping Secret for Students}

Headteacher understands and knows the students more than other teachers do, so he/she is more familiar with students' situation and students are also willing to talk to the headteacher about some secrets that they never tell their parents or other classmates. Therefore, the headteacher should keep students' secrets in strictly confidential and respect the students to win trust from students. The headteacher also should try to work out some ideas for students to solve problems in study and in life.

\section{Being Considerate to Students}

Some students have some defects and shortcomings. In class conversation, the headteacher shall avoid the topics involved in those defects and shortcomings and it will protect student's negative face by individual conversation to avoid awkwardness for this student.

\section{Reducing Harm to Students’ Negative Face}

When the speaker requests the hearer to help or gives suggestions or orders to the hearer, the speaker can show his/her politeness through reducing these behaviors' harms to the negative face of the hearer. (Liu, 2002: 76) Sometimes, in front of many people, many students are afraid of making linguistic mistakes because they believe they will lose face if they do, so they are unwilling to answer some difficult questions. But the headteacher can eliminate students' mental obstacles through reducing the harm to the negative face of the students. If the headteacher blames the student in front of the whole class with impatient tone, the excessive face to face denying is easy to harm student's confidence and enthusiasm.

\section{Conclusion}

From the perspective of psychics, "respect" is a need of human beings. Students, in particular, need more respects from others as their personalities are developing and forming, so they will become more capable, positive, confident and creative in life and study. Conversely, if they are not respected, their self-doubt, self-denial and self-abasement and cowardice will be induced. They will become more indifferent to life and study. Politeness strategies are the summary of headteacher's working methods. The application of the politeness strategies is a kind of skill, an art and a need to implement the quality-oriented education. It can activate classroom atmosphere, harmonize the teacher-student relationship, improve students' enthusiasm and help the formation of good class atmosphere and the healthy growth of students through proper and smart application of politeness strategies. In my over ten-year class work, I deeply realize that "Only when loving students can teachers actually care for students; only when respecting students can teachers require students; only when understanding students can teachers educate students." Therefore, headteachers are supposed to value politeness strategies in their work, strengthen the study of language management theories and consciously make use of the linguistic theory and knowledge to guide the education and teaching activities.

\section{References}

[1] Z. R. He, Pragmatics and English Learning, Shanghai Foreign Language Education Press, 1997.

[2] H. M. Liu, Modern Educational Principles, Central Radio \& TV University Press, 2002.

[3] G. J. Jia, Psychology of Foreign Languages Education, Guangxi Education Press, 1996.

[4] K. J. Qiu, Essentials of Pedagogy, Parenting Science, Beijing Publishing Group, 1993. 